\title{
Perjanjian Jual Beli Buku Pemilik Kendaraan Bermotor Tanpa Kendaraan Pada Aplikasi Facebook.
}

\author{
Tyas Yuniawati Suroto1, I Made Sarjana²
}

${ }^{1}$ Budi Mustika Nugraha Law Office, E-mail: tyasyuniaaa@gmail.com

2 Fakultas Hukum Universitas Udayana, E-mail: made_sarjana@unud.ac.id

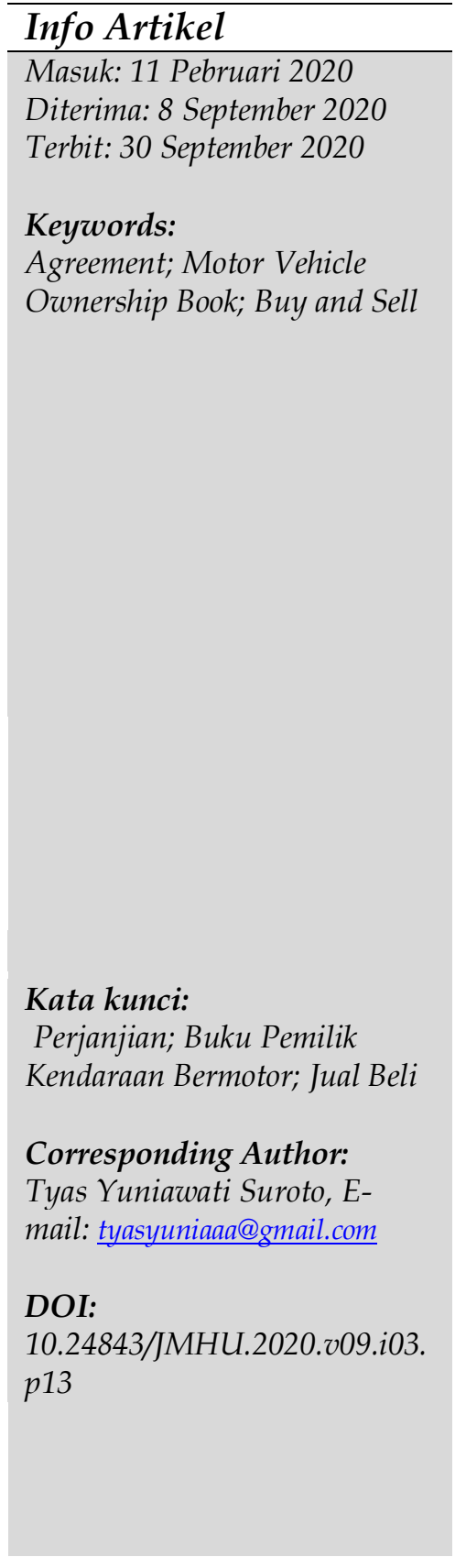

\begin{abstract}
This study aims to analyze the validity of the Motor Vehicle Owner's Book sale and purchase agreement on the Facebook application in relation to the principle of freedom of contract and to analyze the legal consequences of the Motor Vehicle Owner's Book sale and purchase agreement on the Facebook application which is expected to be a benchmark for how it should be regulated regarding selling and buy this Motor Vehicle Owner's Book in the future. This study uses a normative legal research method with a statutory approach and a conceptual approach. The legal materials used are sources of primary legal materials, sources of secondary legal materials and sources of tertiary legal materials. The technique of collecting legal materials used is an argumentative technique and descriptive analysis technique. The results of the research show that the sale and purchase agreement for a Motor Vehicle Owner's Book without a vehicle is a valid agreement as long as the agreement meets the legal requirements of an agreement set out in Article 1320 of the Civil Code. The legal consequence of this agreement is that it can be canceled if it does not meet the subjective requirements and is null and void if the objective conditions are not met. In the BPKB sale and purchase agreement without a vehicle, it is clear that if the objective conditions are not met, then the agreement is null and void or the existence of the agreement is deemed not to exist from the start.
\end{abstract}


Kendaraan Bermotor tanpa disertai kendaraan merupakan perjanjian yang sah sepanjang perjanjian tersebut memenuhi syarat sahnya sebuah perjanjian yang tertuang di dalam Pasal 1320 Kitab Undang-Undang Hukum Perdata. Akibat hukum dari adanya perjanjian ini yaitu dapat dibatalkan apabila tidak memenuhi syarat subyektif dan batal demi hukum apabila syarat obyektifnya tidak terpenuhi. Dalam perjanjian jual beli BPKB tanpa kendaraan sudah jelas apabila syarat obyektifnya tidak terpenuhi maka perjanjian tersebut batal demi hukum atau keberadaan perjanjian tersebut sejak awal dianggap tidak ada.

\section{Pendahuluan}

Latar belakang penelitian ini adalah dengan derasnya arus globalisasi yang terjadi, yang telah menimbulkan berbagai masalah pada hampir seluruh aspek kehidupan manusia di bidang politik, sosial, budaya, ekonomi, ilmu pengetahuan dan teknologi sehingga terjadi perubahan-perubahan yang mendasar. Seiring dengan perubahan pada seluruh aspek tersebut berdampak pada berubahnya pula tatanan pola tingkah laku sosial manusia dalam masyarakat, maka aspek hukum pun harus berubah. Hukum harus diatur agar tercipta ketertiban dalam masyarakat. Hal ini memerlukan payung hukum. Dengan demikian dapat dikatakan bahwa hukum tidak boleh statis, tetapi harus dinamis, dan selalu diadakan perubahan sejalan dengan perkembangan zaman serta dinamika kehidupan sosial dalam masyarakat. ${ }^{1}$

Perkembangan dari teknologi di zaman modern seperti ini membawa perubahan yang sangat pesat dikalangan masyarakat, terutama dalam hal aksesibilitas maupun mobilitas. Jika pada zaman dahulu orang-orang memanfaatkan binatang seperti unta, kerbau dan sapi sebagai alat transportasi apabila ingin bepergian jauh maka sekarang hal tersebut sudah tidak diperlukan lagi karena alat transportasi seperti motor, mobil dan yang lainnya sudah tersebar dimana-mana dan dapat dimiliki dengan harga yang terjangkau tergantung dari spesifikasi kendaraan tersebut. Alat transportasi yang paling sering digunakan oleh warga Indonesia yaitu kendaraan roda dua atau motor, dikarenakan harganya yang bersahabat dan cara menggunakannya yang mudah membuat alat transportasi ini sangat diminati disusul dengan kendaraan roda empat atau mobil yang biasanya dimiliki oleh orang dengan ekonomi menengah ke atas. Selain motor dan mobil yang biasanya digunakan untuk alat transportasi manusia, terdapat juga truk yang biasanya digunakan untuk memindahkan benda yang banyak misalnya pasir, semen maupun digunakan pada saat pindah rumah untuk membawa alat-alat rumah tangga.

Buku Pemilik Kendaraan Bermotor atau yang selanjutnya disebut BPKB merupakan buku yang diperoleh dari "Satuan Lalu Lintas Polisi Republik Indonesia" atau yang selanjutnya disebut SATLANTAS POLRI yang dimana buku tersebut sangat berguna untuk membuktikan bahwa kendaraan tersebut merupakan milik dari seseorang yang namanya tercantum di dalam BPKB tersebut. Tertuang di dalam Pasal 1 angka 8 Perkapolri Nomor 5 Tahun 2012 Tentang Registrasi dan Identifikasi Kendaraan Bermotor menyatakan bahwa BPKB adalah dokumen pemberi legitimasi pemilik

\footnotetext{
1 Sidik, S. (2013). Dampak Undang-Undang Informasi dan Transaksi Elektronik (UU ITE) terhadap Perubahan Hukum dan Sosial dalam Masyarakat. Jurnal Ilmiah Widya, 4(2).
} 
kendaraan bermotor yang diterbitkan Polri dan berisi identitas kendaraan bermotor dan pemilik, yang berlaku selama kendaraan bermotor tidak dipindah tangankan. Adanya pendaftaran BPKB secara tidak langsung akan menghasilkan Surat Tanda Nomor Kendaraan atau yang selanjutnya disebut dengan STNK, dimana STNK ini berfungsi untuk memberikan identitas terhadap kendaraan tersebut agar tidak tertukar dengan kendaraan lainnya. STNK juga tertuang dalam Pasal 1 angka 9 Perkapolri Nomor 5 Tahun 2012 Tentang Registrasi dan Identifikasi Kendaraan yang menyatakan bahwa STNK adalah dokumen yang berfungsi sebagai bukti legitimasi pengoperasian kendaraan bermotor yang berbentuk surat atau bentuk lain yang diterbitkan Polri yang berisi identitas pemilik, identitas kendaraan bermotor dan masa berlaku termasuk pengesahannya. BPKB merupakan salah satu surat berharga di Indonesia dan dapat disamakan dengan certificate of ownership yang merupakan dokumen penting. ${ }^{2}$ Adapun yang pasti terdapat di dalam sebuah BPKB yaitu keterangan kepabean, identifikasi kendaraan bermotor, catatan mengenai perubahan pemilik kendaraan bermotor, pendaftaran polisi, catatan pelunasan pajak/BBN, catatan pejabat Polisi Lalu Lintas serta keterangan.

BPKB itu sendiri berbentuk buku berukuran 17x12 centimeter dengan lembar kulit berwarna biru tua dan tulisan putih perak yang berisikan dengan nomor BPKB. Di dalam BPKB itu sendiri terdiri dari 22 halaman dengan warna dasar keabu-abuan. Mengenai data identifikasi kendaraan bermotor seperti nomor polisi, tipe, merk, tahun pembuatan, nomor rangka, nomor mesin dan juga asal usul kendaraan seperti negara mana yang membuat kendaraan tersebut, nama perusahaan penjual atau dealer, cara impor serta nama pembeli maupun pemilik merupakan hal-hal yang tertuang dalam BPKB suatu kendaraan. BPKB dapat dikatakan memiliki nilai yuridis sebagai bukti Pemilik yang sah sehingga memiliki nilai ekonomis yang artinya dapat dijadikan jaminan dalam hal transaksi keuangan. BPKB itu sendiri tidak harus selalu dibawa pada saat membawa kendaraan tersebut dan disarankan untuk ditaruh pada tempat yang aman agar tidak disalahgunakan oleh orang yang tidak bertanggung jawab. Dalam hal inilah peran STNK sangatlah penting sebagai pengganti dari BPKB yang dimana isi dari STNK merupakan hal-hal yang spesifik yang ada dalam kendaraan tersebut.

Tidak semua kendaraan bermotor selalu memiliki BPKB, sejarah kemunculan dari BPKB itu sendiri terjadi dikarenakan adanya pembelian dari sebuah kendaraan. Apabila telah mencapai kesepakatan pembelian yang dilakukan di dealer, maka motor dapat dipindah tangankan kepada pembeli dan surat BPKB akan segera dibuat dan diserahkan kepada pembeli kendaraan tersebut. Berdasarkan hal tersebut maka setiap kendaraan pasti memiliki BPKB apabila telah dilakukannya pembelian terhadap kendaraan tersebut. Apabila BPKB hilang atau rusak, maka kepengurusannya pun sangat rumit dan membutuhkan waktu lama untuk mengurus BPKB tersebut. Dikarenakan hal tersebut, maka merawat dan menjaga buku satu ini sangatlah penting. Dalam mengurus BPKB yang rusak sebenarnya hampir sama dengan kepengurusan $\mathrm{BPKB}$ baru, hanya saja terdapat persyaratan tertentu dalam mengurus BPKB hilang rusak. Terdapat persyaratan tambahan apabila BPKB ini rusak, yaitu harus menyerahkan BPKB yang rusak tersebut ke petugas. Sedangkan untuk pengurusan $\mathrm{BPKB}$ yang hilang lebih rumit dibandingkan dengan pengurusan $\mathrm{BPKB}$ yang rusak. Pengurusannya pun hampir sama dengan pengurusan BPKB baru, hanya

2 Polisi Republik Indonesia, Url: https://www.polri.go.id/layanan-bpkb 
saja ditambahkan dengan persyaratan bukti penyiaran di media massa cetak atas BPKB hilang dan melampirkan surat kehilangan dari pihak-pihak lainnya.

Melalui internet saat ini mulai tumbuh komunitas-komunitas yang mengkhususkan diri dalam memperdagangkan barang-barang tertentu. Pelaku-pelaku bisnis sekarang mulai bergabung dalam situs-situs yang mewadahi komunitas mereka. Situs-situs tersebut mewajibkan penggunanya untuk menjadi anggotanya terlebih dahulu, namun ada juga yang tidak. Sebagaimana sebuah toko online yang menawarkan barang untuk diperjualbelikan melalui internet (Ecommerce). ${ }^{3}$

Aplikasi Facebook merupakan situs jejaring sosial yang sudah terkenal sejak lama di Indonesia, semakin hari penggunaan Facebook semakin meningkat diikuti dengan pembaharuan-pembaharuan fitur yang menarik. Aplikasi Facebook juga merupakan salah satu aplikasi yang dirasa tidak lekang oleh perkembangan zaman, seperti yang diketahui Facebook bahkan muncul sebelum adanya aplikasi Path, Blackberry Messenger, Wechat dan sederet aplikasi lainnya yang kini sudah tidak diminati oleh orang-orang. Aplikasi Facebook memang merupakan aplikasi yang sangat membantu di kehidupan masyarakat, selain untuk memposting sesuatu mengenai profil diri maupun hal-hal seperti status, foto maupun video namun kini Facebook juga banyak digunakan untuk kegiatan komersil seperti transaksi-transaksi online.

Transaksi online yang terdapat dalam aplikasi Facebook biasanya dapat ditemui pada laman-laman grup yang dimana biasanya grup-grup tersebut terpisah sesuai dengan benda apa yang ingin dibeli oleh calon pembeli. Misalnya yang paling sering ditemui yaitu laman jual beli mobil atau motor bekas, jual beli handphone atau smartphone, info jual rumah, sewa kos, jual beli pakaian dan yang lainnya. Segala hal bisa dijual melalui laman Facebook dan dapat dikatakan bahwa apabila menjual sesuatu di Facebook barang tersebut akan cepat laku dikarenakan banyaknya peminat. Maka tidak heran bahwa pengguna Facebook seakan sulit untuk berpaling dari banyaknya keuntungan yang ditawarkan oleh aplikasi Facebook ini.

Pada aplikasi Facebook itu sendiri juga tidak jarang ditemukan orang-orang yang menjual kendaraan bermotor tanpa BPKB maupun STNK, hal ini sudah jelas merupakan hal yang bertentangan dengan hukum. Namun adanya harga yang murah yang ditawarkan oleh penjual membuat banyak orang tertarik untuk membeli kendaraan tersebut dan mengabaikan akibat dari adanya transaksi tersebut. Bukan rahasia umum lagi apabila motor yang dijual tanpa surat atau yang biasa disebut dengan motor bodong kebanyakan merupakan motor hasil curian, sehingga apabila pihak kepolisian menemukan motor tanpa surat, motor tersebut akan ditahan hingga orang yang membawa motor tersebut mampu menunjukkan surat-surat lengkap dari adanya motor tersebut.

Penjualan motor bodong merupakan hal yang sudah biasa terjadi di Indonesia, namun bagaimana dengan penjualan BPKB tanpa adanya kendaraan yang kini mulai marak di aplikasi Facebook. Orang-orang tersebut bahkan secara terang-terangan menawarkan BPKB yang ia miliki pada laman grup yang diberi nama Jual Beli Mesin/STNK/BPKB Only, dimana pada laman grup tersebut memang diperuntukkan bagi orang-orang yang ingin membeli STNK maupun BPKB kendaraan tanpa harus menyerahkan

\footnotetext{
3 Anggraeni, R. D., \& Rizal, A. H. (2019). Pelaksanaan Perjanjian Jual Beli Melalui Internet (ECommerce) Ditinjau Dari Aspek Hukum Perdataan. SALAM: Jurnal Sosial dan Budaya Syar$i, 6(3), 223-238$.
} 
kendaraan secara fisik. Tidak tanggung-tanggung harga yang ditawarkan sangat bervariasi tergantung dari merk, jenis dan tahun penerbitan BPKB maupun STNK tersebut, semakin baru tahunnya maka semakin mahal harga yang ditawarkan, berkisar antara 700 ribu hingga 7 juta untuk jenis motor dan 7 juta hingga 20 juta untuk mobil, bahkan BPKB tersebut tidak jarang sudah disertai dengan pajak yang masih aktif atau baru dibayarkan. Asas kebebasan berkontrak merupakan asas yang penting di dalam pembuatan sebuah perjanjian dimana asas ini tertuang di dalam Pasal 1338 KUH Perdata yang menyatakan "Semua kontrak atau perjanjian yang dibuat secara sah berlaku sebagai Undang-Undang bagi mereka yang membuatnya." Adanya kebebasan berkontrak ini bersumber dari kebebasan individu untuk menentukan isi, obyek maupun hal-hal yang terdapat dalam kontrak perjanjian tersebut. Adanya kebebasan berkontrak ini memang sangat berkaitan dengan adanya transaksi elektronik, dimana kebebasan ini juga memberikan ruang yang luas kepada setiap individu untuk melakukan sebuah perjanjian baik secara langsung maupun secara tidak langsung.

Adapun rumusan masalah yang akan diteliti yaitu bagaimanakah keabsahan perjanjian jual beli BPKB pada aplikasi Facebook dikaitkan dengan asas kebebasan berkontrak dan bagaimanakah akibat hukum dari adanya perjanjian jual beli BPKB pada aplikasi Facebook tersebut. Sehingga secara tidak langsung tujuan dari penulisan ini adalah untuk mengetahui keabsahan perjanjian jual beli BPKB pada aplikasi Facebook dikaitkan dengan asas kebebasan berkontrak dan akibat hukum dari adanya perjanjian jual beli BPKB pada aplikasi Facebook yang diharapkan akan menjadi tolak ukur mengenai bagaimana seharusnya diatur mengenai jual beli BPKB ini di masa mendatang. Adapun yang menjadi State Of The Art dari penulisan ini menggunakan jurnal yang dibuat oleh saudari Lisnawati yang berjudul "Motor Kawin: Suatu Bentuk Pemanfaatan Secara Tidak Sah Surat Tanda Nomor Kendaraan Bermotor" dimana dalam penelitian ini memiliki fokus yang sama yaitu meneliti mengenai BPKB yang dipergunakan untuk motor lainnya dengan jenis yang sama. Yang membuat penelitian ini berbeda adalah dikarenakan fokus penelitian dari saudari Lisnawati adalah mengenai kriminologi dari adanya $\mathrm{BPKB}$ yang digunakan untuk motor lainnya, sedangkan dalam penelitian ini fokus yang akan diteliti adalah mengenai keabsahan perjanjian jual beli BPKB tanpa kendaraan yang kini marak terjadi pada aplikasi Facebook.

\section{Metode Penelitian}

Penulisan dalam penelitian ini dilakukan dengan menggunakan metode penelitian hukum normatif yaitu metode yang digunakan di dalam penelitian hukum yang dilakukan dengan cara meneliti bahan pustaka yang ada. Penelitian hukum normatif ini dilakukan dikarenakan adanya kekosongan norma hukum mengenai hal yang berkaitan dengan mekanisme pengalihan BPKB ke motor yang bukan motor sebenarnya. Adapun Pendekatan dalam penelitian ini menggunakan Pendekatan Perundang-Undangan. Menggunakan Pendekatan perundang-undangan dikarenakan pendekatan ini dilakukan dengan menelaah semua peraturan perundang-undangan yang bersangkut paut dengan permasalahan atau isu hukum yang sedang dihadapi. ${ }^{4}$

\footnotetext{
${ }^{4}$ Johnny Ibrahim, 2013, Teori dan Metodologi Penelitian Hukum Normatif, Bayu Media Publishing, Malang, h.302
} 
Dalam penelitian ini digunakan berbagai sumber bahan hukum yaitu diantaranya “Kitab Undang-Undang Hukum Perdata, Undang-Undang Nomor 19 Tahun 2016 Tentang Perubahan Atas Undang-Undang Nomor 11 Tahun 2008 Tentang Informasi dan Transaksi Elektronik, Peraturan Kepolisian Republik Indonesia Nomor 5 Tahun 2012 Tentang Registrasi dan Identifikasi Kendaraan Bermotor." Penelitian ini juga menggunakan teknik deskripsi dimana teknik ini adalah teknik dasar analisis yang tidak dapat dihindarkan penggunaannya. Deskripsi berarti menguraikan apa adanya terhadap suatu kondisi atau posisi dari proposisi-proposisi hukum atau non hukum. Selain menggunakan teknik deskripsi, teknik argumentasi hukum merupakan teknik yang tidak kalah pentingnya dimana teknik argumentasi hukum merupakan teknik analisis dengan penilaian yang berdasarkan pada alasan-alasan yang bersifat penalaran hukum.

\section{Hasil dan Pembahasan}

\subsection{Keabsahan perjanjian jual beli BPKB tanpa kendaraan pada aplikasi Facebook dikaitkan dengan asas kebebasan berkontrak.}

E-Commerce menciptakan suatu transaksi bisnis yang lebih praktis tanpa menggunakan kertas dan tanpa melakukan pertemuan secara langsung (face to face). ${ }^{5}$ Transaksi jual beli saat ini tidak lagi dibatasi oleh jarak dan waktu, seiring dengan perkembangan tekhnologi internet, transaksi ini dapat dilakukan kapanpun dimanapun melalui dunia maya, salah satunya yaitu melalui suatu grup-grup online yang terdapat pada jejaring sosial Facebook. Penjualan barang melalui media sosial Facebook sangat menguntungkan bagi orang-orang yang biasa melakukan perdagangan di dunia nyata. Kemudahan yang diberikan dari adanya penjualan melalui media sosial yaitu tidak perlunya untuk melakukan pemasaran di lapangan seperti yang sering dilakukan sebelum adanya media internet, seseorang yang ingin memasarkan dagangannya harus mencari lapak atau tempat yang tentu saja akan menghabiskan biaya lebih dan waktu yang panjang untuk memasarkan barang tersebut. Maka memang benar pernyataan yang menyatakan bahwa internet memudahkan segala bentuk kegiatan manusia.

Banyak pelaku usaha yang menggunakan Facebook untuk berbisnis, bahkan sebelum jejaring sosial besutan Mark Zuckerberg ini melahirkan fitur Fanpage. Dikarenakan pengguna Facebook paling banyak dibanding media sosial lain. Penjualan barang dalam aplikasi Facebook biasanya dikelompokkan masing-masing dalam bentuk grup-grup sehingga memudahkan dalam pencarian, misalnya grup "jual beli vape di Bali" atau "Jual beli mobil di Bali" sehingga apabila seseorang ingin membeli Vape atau mobil di daerah Bali hanya perlu bergabung dengan grup dan membaca postingan-postingan yang ada dalam laman grup tersebut. Kelebihan lain berjualan di Facebook yaitu dapat mengulas produk lebih detail dan panjang. Fitur comment memudahkan untuk melihat feedback atau umpan balik dari calon konsumen atau testimoni dari para pelanggan.

Salah satunya yang menarik perhatian dalam dunia jual beli Facebook yaitu banyaknya laman penjualan BPKB tanpa adanya motor. Adanya penjualan BPKB tanpa kendaraan bermotor memang bukanlah sesuatu yang dilarang di Indonesia, namun hal tersebut masih sangat terdengar tabu di kalangan masyarakat yang tidak mengerti masalah

\footnotetext{
${ }^{5}$ Bintoro, R. W. (2011). Penerapan Hukum dalam Penyelesaian Sengketa Transaksi Elektronik di Peradilan Umum. Jurnal Dinamika Hukum, 11(2), 258-272.
} 
motor. Biasanya untuk mendapatkan STNK dan BPKB kendaraan bermotor harus disertai satu unit motor dan faktur resmi yang diberikan dari dealer. Namun, tanpa perlu memenuhi syarat tersebut banyak ditemui STNK dan BPKB asli yang dijual secara bebas. Perlu dicatat bahwa STNK dan BPKB yang dijual ini bukanlah untuk motor baru, melainkan motor bekas. Terdapat banyak alasan mengapa orang mau membeli BPKB tanpa kendaraan yaitu diantaranya surat-surat kendaraan hilang dan ada juga yang hilang nomor mesin atau nomor sasis karena motor sudah tua atau pecah atau rusak karena kecelakaan. Sedangkan bagi para pemilik STNK dan BPKB, melakukan penjualan ketengan ini memberikan keuntungan yang lebih banyak daripada menjual satu motor utuh.

Harga yang ditawarkan dalam penjualan STNK dan BPKB melalui aplikasi Facebook sangat bervariasi dan tergantung dari jenis kendaraan dalam surat Pemilik tersebut, mulai dari 750 ribu hingga 8 juta untuk jenis motor dan belasan juta untuk kendaraan roda empat, namun yang paling populer penjualannya dalam aplikasi Facebook yaitu penjualan motor dengan jenis Honda Tiger. Dikarenakan penjualan ini dilakukan melalui dunia online maka tidak jarang dalam pelaksanaannya penjual dan pembeli tidak bertemu, pembeli akan mentransfer sejumlah uang sesuai dengan kesepakatan harga dan penjual akan mengirimkan barang tersebut yang dalam hal ini adalah surat Pemilik kendaraan ke alamat pembeli tersebut. Hanya bermodalkan rasa saling percaya maka perjanjian tersebut dapat dilakukan. Memang bukan rahasia umum lagi bahwa perjanjian jual beli online terkadang memberikan kemudahan yang menggiurkan namun juga memberikan resiko yang besar, misalnya apabila barang tersebut tidak sesuai dengan ekspektasi atau barang tersebut ternyata palsu, sehingga apabila ingin melakukan transaksi online harus dengan pertimbangan yang matang dan kepercayaan yang besar terhadap penjual barang tersebut.

Sebuah kontrak perdagangan dianggap sah secara hukum jika memenuhi persyaratan secara subyektif dan obyektif, jika salah satu syarat tidak dapat dipenuhi maka kontrak perdagangan tersebut dapat dimintakan pembatalan (syarat subyektif tidak terpenuhi) atau dapat batal demi hukum (syarat obyektif tidak terpenuhi). Secara yuridis, di Indonesia, syarat-syarat sahnya sebuah perjanjian tertuang dalam Pasal $1320 \mathrm{Kitab}$ Undang-undang Hukum Perdata (KUHPerdata), dimana pasal tersebut mensyaratkan 4 hal agar perjanjian dianggap sah secara hukum yaitu: 1) adanya kesepakatan dari para pihak; 2) kecakapan melakukan perbuatan hukum; 3) adanya sebab yang halal; dan 4) adanya objek tertentu. Dua syarat pertama dikategorikan sebagai syarat subyektif dan dua syarat terakhir dikategorikan sebagai syarat obyektif. ${ }^{6}$

Keabsahan perjanjian jual beli melalui media online yang dalam hal ini adalah aplikasi Facebook sebenarnya sangat mirip dengan perjanjian jual beli secara konvensional dimana pihak penjual dan pihak pembeli bertemu lalu melakukan perjanjian. Mengenai perjanjian tertuang di dalam ketentuan Pasal 1320 Kitab Undang-Undang Hukum Perdata dimana terdapat syarat sahnya suatu perjanjian. Dengan demikian perjanjian atau kontrak merupakan sarana untuk memastikan bahwa apa yang hendak dicapai para pihak dapat diwujudkan, karena pada dasarnya kontrak dibuat untuk menghindari terjadinya kerugian antara pihak satu dengan pihak lainnya. Untuk menentukan atau menilai keabsahan kontrak yang dituangkan dalam perjanjian harus dikaji bagaimana hukum kontrak mengatur syarat-syarat keabsahan suatu perjanjian.

${ }^{6}$ Akhmaddhian, S., \& Agustiwi, A. (2018). Perlindungan Hukum Terhadap Konsumen Dalam Transaksi Jual Beli Secara Elektronik Di Indonesia. UNIFIKASI: Jurnal Ilmu Hukum, 3(2), 40-60. 
Perjanjian jual beli secara umum di Indonesia diatur dalam Kitab Undang-Undang Hukum Perdata (KUH Perdata) Pasal 1457 sampai dengan Pasal 1540. Jual beli adalah suatu perjanjian, dengan mana pihak yang satu mengikatkan dirinya untuk menyerahkan suatu kebendaan dan pihak yang lain untuk membayar harga yang telah dijanjikan. Menurut Pasal 4 Undang-Undang Perlindungan Konsumen yang disingkat dengan UUPK, menyatakan bahwa: Konsumen memiliki hak dalam kegiatan jual beli. Sebagaimana tercantum dalam Undang-undang Republik Indonesia Nomor 8 Tahun 1999 tentang Perlindungan Konsumen (UUPK) Hak-hak yang diberikan kepada konsumen ini bertujuan untuk memberikan perlindungan bagi konsumen. ${ }^{7}$

Hukum adalah sebuah kepastian karena hukum ditujukan untuk meningkatkan kebahagiaan masyarakat secara keseluruhan dengan cara melarang perbuatanperbuatan yang mendatangkan sengsara. Maka dari itu manusia di dalam pergaulan masyarakat diliputi oleh norma-norma, dimana kegunaan norma itu bagi manusia adalah untuk memberi petunjuk bagi manusia bagaimana seorang harus bertindak dalam masyarakat serta perbuatan-perbuatan mana yang harus dijalankan dan perbuatan-perbuatan mana pula yang harus dihindari. Adapun tolak ukur keabsahan perjanjian tersebut diatur dalam Pasal 1320 Kitab Undang-Undang Hukum Perdata. Dengan demikian perjanjian atau kontrak merupakan sarana untuk memastikan bahwa apa yang hendak dicapai para pihak dapat diwujudkan, karena pada dasarnya kontrak dibuat untuk menghindari terjadinya kerugian antara pihak satu dengan pihak lainnya. Untuk menentukan atau menilai keabsahan kontrak yang dituangkan dalam perjanjian harus dikaji bagaimana hukum kontrak mengatur syarat-syarat keabsahan suatu perjanjian.

Pembuatan suatu perjanjian hendaklah memperhatikan hal-hal penting, antara lain syarat-syarat sahnya perjanjian, asas-asas perjanjian, hak dan kewajiban para pihak, struktur dan anatomi pembuatan kontrak, penyelesaian perselisihan dan berakhirnya kontrak. ${ }^{8}$ Sesuai dengan Pasal 1320 Kitab Undang-Undang Hukum Perdata menentukan adanya 4 (empat) syarat sahnya suatu perjanjian yakni yang pertama disebut dengan syarat subyektif yaitu adanya kesepakatan dan kecakapan untuk membuat suatu perjanjian. Adanya kesepakatan merupakan persesuaian antara pernyataan kehendak antara satu atau lebih dengan pihak lainnya, sedangkan adanya kecakapan bagi pembuat perjanjian yaitu perjanjian tidak dapat dilakukan oleh orangorang yang belum dewasa dan orang-orang yang berada dibawah pengampunan. Orang-orang yang belum dewasa sebagaimana ditentukan dalam Pasal $330 \mathrm{KUH}$ Perdata adalah mereka yang belum genap berusia 21 tahun dan tidak kawin sebelumnya. Sedangkan mereka yang berada di bawah pengampunan sesuai dengan Pasal 433 KUH Perdata adalah orang dungu, sakit otak, mata gelap dan boros. Kedunguan, sakit otak, mata gelap dan boros harus dibuktikan dimana orang yang bersangkutan telah ditaruh di bawah pengampunan berdasarkan penetapan pengadilan. ${ }^{9}$

\footnotetext{
${ }^{7}$ Dewi, M. N. K. (2017). Penyelesaian Sengketa Dalam Perjanjian Jual Beli Secara Online. Jurnal Cahaya Keadilan, 5(2), 72-90.

8 Prasnowo, A. D., \& Badriyah, S. M. (2019). Implementasi Asas Keseimbangan Bagi Para Pihak Dalam Perjanjian Baku. Jurnal Magister Hukum Udayana, 8(1).

${ }_{9}^{9}$ Abdul Kadir Muhammad, 2004, Hukum Perjanjian, Pustaka Yustitia, Bandung, h.6
} 
Syarat subyektif memang menentukan seseorang berdasarkan dari kondisi orang yang membuat perjanjian tersebut, apabila ia layak disebut sebagai subyek hukum maka orang tersebut diperkenankan untuk membuat sebuah perjanjian. Selain syarat subyektif terdapat pula syarat obyektif, dimana syarat obyektif ini lebih memfokuskan diri pada yang menjadi obyek dalam perjanjian tersebut. Syarat obyektif terdiri dari suatu hal tertentu, artinya dalam membuat perjanjian apa yang menjadi obyek dari perjanjian tersebut haruslah jelas, selain itu maksud dari hal tertentu di sini adalah objek dari perjanjian, baik berupa barang atau jasa yang dapat dinilai dengan uang. Pasal 1332 KUH Perdata menentukan bahwa "Hanya barang-barang yang dapat diperdagangkan yang dapat menjadi pokok perjanjian". Hal tersebut berarti pokok perjanjian harus dapat dinilai dengan uang. Barang-barang yang menjadi objek perjanjian harus dapat ditentukan secara jelas dan pasti. Pasal 1333 KUH Perdata menentukan "Suatu perjanjian harus mempunyai pokok suatu barang yang paling sedikit ditentukan jenisnya". Barang paling sedikit dapat ditentukan jenisnya, misalnya jenis barang yang tampak oleh mata dan dapat ditentukan dengan cara menghitung, menimbang, mengukur menakar, menentukan kualitas. Masih mengenai syarat obyektif sebuah perjanjian, dimana suatu sebab yang halal juga merupakan hal yang sangat diperlukan dalam sebuah perjanjian, mengingat apabila hal ini tidak ada maka akan banyak terjadi penipuan, wanprestasi atau perbuatan melawan hukum yang tentu saja akan memberikan kerugian bagi salah satu pihak. Suatu sebab yang halal dalam hal ini yaitu arti perjanjian itu sendiri menggambarkan tujuan yang akan dicapai oleh para pihak dan dibenarkan oleh Undang-Undang, ketertiban umum, kepatuhan, dan kesusilaan. Yang diperhatikan oleh undang-undang yakni isi dari perjanjian tersebut, yang menggambarkan tujuan yang akan dicapai, apakah dilarang oleh undang-undang atau tidak, apakah bertentangan dengan ketertiban umum, kepatuhan, dan kesusilaan atau tidak.

Pasal 1320 KUH Perdata juga didukung dengan beberapa asas yang melekat pada perjanjian yaitu salah satunya adalah asas kebebasan berkontrak, asas ini terbentuk dari adanya Pasal 1338 KUH Perdata yang menyatakan asas kebebasan berkontrak mengandung pengertian bahwa para pihak bebas mengatur sendiri isi kontrak atau perjanjian tersebut. Meskipun demikian, kebebasan melakukan kontrak tidak bersifat sebebas-bebasnya. Kebebasan para pihak dalam melakukan perjanjian dibatasi sepanjang kontrak tersebut memenuhi syarat sebagai suatu kontrak serta tidak bertentangan dengan Undang-Undang, kesusilaan dan ketertiban umum. Adanya asas kebebasan berkontrak selain menentukan isi dari perjanjian tersebut para pihak juga diperbolehkan untuk menentukan pelaksanaannya maupun bentuk kontraknya, sehingga perjanjian yang dilakukan dengan tidak bertemu secara langsung, dilakukan melalui aplikasi Facebook dan pelaksanaannya atas dasar kesepakatan yang dilakukan dengan bantuan media chatting dapat dilakukan.

Maka dalam hal ini dapat disimpulkan bahwa perjanjian jual beli BPKB tanpa kendaraan dapat dikatakan sah apabila memenuhi syarat sahnya sebuah perjanjian, dimana penjual maupun pembeli harus cakap hukum dan bersedia melakukan kesepakatan, obyek dari perjanjian tersebut haruslah jelas dan tidak bertentangan dengan hukum. Meskipun perjanjian jual beli BPKB tanpa kendaraan merupakan hal yang tabu, namun untuk berbagai kalangan hal ini merupakan hal yang sudah biasa dilakukan. Biasanya orang yang menjualkan BPKB tanpa kendaraan adalah orangorang yang motornya dicuri hingga hanya tersisia surat saja, atau orang yang menjual motornya dengan tidak utuh, yang dijual adalah mesinnya, rangka, cover dan yang 
lainnya, dalam pelaksananya menjual motor perbagian akan memberikan keuntungan yang berlipat ganda dibandingkan dengan menjual motor utuh, sehingga hal inilah yang menarik minat dari penjual untuk memasarkan bagian-bagian motornya secara terpisah. Hal inilah yang menjadi dasar pemikiran bahwa lebih baik surat-surat tersebut dijual daripada dibuang atau hanya disimpan karena dapat menghasilkan uang. Bagi pihak yang memanfaatkannya hal ini juga sangat memberikan keuntungan bagi negara dikarenakan pajak dari kendaraan tersebut akan selalu dibayar, sehingga hal ini dianggap membantu negara. Pada intinya penjualan BPKB tanpa kendaraan memang belum diatur dengan jelas mengenai mekanismenya, apakah hal tersebut diperbolehkan atau tidak sehingga masih ada kerancuan dalam pelaksanaannya. Namun apabila diteliti berdasarkan perjanjiannya maka hal tersebut dapat dianggap sah selama memenuhi unsur yang tertuang dalam Pasal 1320 KUH Perdata.

\subsection{Akibat hukum dari adanya perjanjian jual beli BPKB tanpa kendaraan pada aplikasi Facebook.}

E-Commerce merupakan salah satu bentuk transaksi perdagangan yang paling banyak dipengaruhi oleh perkembangan teknologi informasi. Melalui transaksi perdagangan ini konsep pasar tradisional (dimana penjual dan pembeli secara fisik bertemu) berubah menjadi konsep telemarketing (perdagangan jarak jauh melalui internet) $e$ commerce pun telah mengubah cara konsumen dalam memperoleh produk yang diinginkannya. Hubungan dagang tersebut harus dilandasi dengan perjanjian. Sehingga hak dan kewajiban para pihak dapat diatur secara tertulis untuk menghindari resiko di kemudian hari. ${ }^{10}$

Manusia dalam memenuhi kebutuhan hidupnya tidak terlepas dari adanya bantuan dan kerjasama-kerjasama yang dilakukan yang seringkali di dalamnya telah dibuat suatu perjanjian untuk pelaksanaan pekerjaan terhadap kesepakatan yang telah dibuat sebelumnya untuk pemenuhan suatu prestasi, termasuk di dalamnya dalam hal perniagaan yang dilakukan khususnya pada transaksi jual beli. Perjanjian jual beli yang dibuatkan secara sah tidak boleh dibatalkan oleh satu pihak saja. Suatu perjanjian hanya dapat dibatalkan, bilamana ada persetujuan dari kedua belah pihak yang mengadakan perjanjian tersebut. Tetapi dalam prakteknya tidak sedikit dari para pihak yang terlibat dalam suatu perjanjian jual beli, melakukan pelanggaranpelanggaran dengan berbagai macam alasan dan argumen yang cenderung untuk membenarkan mengapa mereka melanggar perjanjian tersebut, seperti misalnya masalah ekonomi seperti turunnya daya beli masyarakat, sehingga menyebabkan perjanjian tidak dapat dipenuhi. ${ }^{11}$

Teknologi internet mempunyai pengaruh yang sangat besar terhadap perekonomian dunia. Internet membawa perekonomian dunia memasuki dunia baru yang lebih populer dengan istilah digital economics atau perekonomian digital. Makin banyak kegiatan perekonomian dilakukan melalui media internet. Semakin banyak orang

${ }^{10}$ Perdana, A., \& Dahlan, M. (2014). Penyelesaian wanprestasi dalam perjanjian jual beli melalui media elektronik. Jurnal Ilmu Hukum, 2(1).

${ }^{11}$ Langi, M. (2016). Akibat Hukum Terjadinya Wanprestasi dalam Perjanjian Jual Beli. Lex Privatum, 4(3). 
mengandalkan jual beli sistem online (e-commerce) sebagai media transaksi. ${ }^{22}$ Dengan perkembangan zaman, dalam melakukan penawaran barang penjual tidak perlu bertemu dengan calon pembeli, calon pembeli dapat melihat barang yang dibutuhkan dalam akun seperti Facebook yang menawarkan fitur jual beli yang biasanya dikelompokkan berdasarkan apa yang ingin dibeli. Hal inilah yang kini atau sedang trend dinamakan dengan jual beli online. Suatu transaksi online juga merupakan suatu perjanjian jual beli yang sama dengan jual beli konvensional pada umumnya.

Kontrak perjanjian yang dilakukan wajib dilakukan dengan memperhatikan syarat sahnya perjanjian karena tanpa hal tersebut kontrak dapat dinyatakan tidak sah. Kontrak perjanjian adalah cara untuk mewujudkan kewajiban dan memastikan para pihak dapat menerima hak-haknya sesuai dengan yang diperjanjikan, misalnya dalam perjanjian jual beli yang melibatkan sesama manusia, penjual berkewajiban untuk menyerahkan barang sedangkan pembeli berkewajiban untuk menyerahkan uang sesuai harga ketika kontrak dilakukan. Berbeda dari perjanjian pada umumnya, perjanjian e-commerce ini dibuat tanpa harus mempertemukan para pihak, karena perjanjian e-commerce ini dalam pembuatannya hanya menggunakan media elektronik. Perjanjian pada umumnya terjadi ketika terdapat kesepakatan diantara kedua belah pihak. Kesepakatan juga merupakan salah satu syarat subyektif sahnya suatu perjanjian menurut KUHPerdata. Dengan kesepakatan dimaksudkan bahwa diantara pihak-pihak yang bersangkutan tercapai suatu kesesuaian kehendak, artinya apa yang dikehendaki oleh yang satu adalah yang dikehendaki oleh yang lain. Maka untuk mengikatkan diri dalam suatu perjanjian, para pihak haruslah terlebih dahulu mencapai kesepakatan. ${ }^{13}$

Sebelumnya telah dijelaskan mengenai syarat sahnya perjanjian dimana harus dipenuhi, syarat tersebut antara lain kesepakatan mereka yang mengikatkan dirinya, kecakapan untuk membuat suatu perikatan, suatu pokok perbuatan tertentu dan suatu sebab yang tidak dilarang. Keempat syarat perjanjian tersebut dikelompokkan dalam dua bentuk unsur yaitu syarat subyektif dan syarat obyektif. Dalam syarat subyektif terdiri dari kesepakatan antara kedua belah pihak yang melakukan perjanjian dan kecakapan hukum, apabila syarat subyektif ini tidak terpenuhi maka perjanjian dapat dibatalkan artinya selama para pihak tidak membatalkan perjanjian, maka perjanjian masih tetap berlaku. Sedangkan yang dimaksud syarat obyektif adalah suatu hal tertentu atau suatu sebab yang halal, dalam hal ini berhubungan dengan obyek yang diperjanjikan dan yang akan dilaksanakan oleh para pihak sebagai prestasi atau utang dari para pihak, apabila syarat obyektif ini tidak terpenuhi, maka perjanjian batal demi hukum yang artinya sejak semula dianggap tidak pernah ada perjanjian.

Terdapat suatu hubungan antara penjual dengan pembeli dalam suatu e-commerce. Hubungan hukum yang menimbulkan hak dan kewajiban yang pada dasarnya telah diatur dalam peraturan hukum disebut hubungan hukum. Dalam hukum perdata diatur tentang hak dan kewajiban orang-orang yang mengadakan hubungan hukum yang meliputi peraturan yang bersifat tertulis berupa hukum adat dan kebiasaan yang hidup dalam masyarakat. Wirjono Prodjodikoro berpendapat bahwa hukum pembuktian adalah Sebagian dari hukum acara pada umumnya. Ada bagian dari

${ }_{12}$ Dewi, S. A. K. (2015). Perjanjian Jual Beli Barang Melalui Elektronik Commerce (E-Com). Jurnal Ilmiah Teknologi Informasi Asia, 9(2), 1-5.

${ }^{13}$ Salami, R. U., \& Bintoro, R. W. (2013). Aletrnatif Penyelesaian Sengketa Dalam Sengketa Transaksi Elektronik (E-Commerce). Jurnal Dinamika Hukum, 13(1), 124-135. 
hukum acara perdata yang mengatur beberapa hak dan kewajiban yang dilimpahkan kepada dua belah pihak dalam suatu acara perdata yaitu unsur-unsur yang bersifat materiil.

Maka dapat disimpulkan bahwa akibat hukum dari adanya perjanjian jual beli BPKB tanpa kendaraan memiliki resiko yang tidak main-main. Saat ini teknologi sangat berkembang pesat yang menyebabkan terkadang anak dibawah umur dapat melakukan transaksi dengan bebasnya. Apalagi sudah bukan rahasia umum pada umur belasan tahun banyak anak-anak yang mulai tertarik dunia otomotif sehingga terkadang mereka membeli sparepart kendaraan melalui online karena harga yang lebih murah. ${ }^{14}$ Penjual terkadang tidak mengindahkan siapa pihak yang membeli selama orang tersebut mampu untuk memberikan keuntungan bagi pihak penjual. Apabila hal ini terjadi maka sudah jelas bahwa hal ini tidak memenuhi ketentuan syarat sahnya sebuah perjanjian, sehingga perjanjian tersebut dapat dibatalkan karena tidak memenuhi syarat subyektif perjanjian. Sedangkan pada pelaksanaannya apabila terdapat penjual yang berbuat curang dalam menjual BPKB tersebut maka perjanjian batal demi hukum. Kecurangan yang biasanya terjadi yaitu tidak sinkronnya nomor mesin dengan nomor yang tertera di BPKB, surat BPKB yang ternyata palsu dan adanya niat tidak baik dari pembeli yang akan menggunakan BPKB tersebut untuk motor hasil curian. Dikarenakan hal ini merupakan perjanjian yang dilakukan secara online, maka biasanya kerugian atau penipuan seperti ini sangat sulit untuk dilacak dan dimintakan pertanggung jawaban. ${ }^{15} \mathrm{Hal}$ inilah yang menjadi resiko terbesar dari adanya perjanjian jual beli yang dilakukan secara online.

\section{Kesimpulan}

BPKB dibuat untuk dapat memberikan bukti nyata bahwa kendaraan yang dimiliki oleh seseorang memang benar merupakan kendaraan yang ia miliki. Fenomena yang banyak saat ini terjadi yaitu adanya penjualan BPKB tanpa disertai dengan kendaraan dari yang tertera di BPKB tersebut. Perjanjian jual beli BPKB tanpa kendaraan dapat dikatakan sah apabila memenuhi syarat sahnya sebuah perjanjian, dimana penjual maupun pembeli harus cakap hukum dan bersedia melakukan kesepakatan, obyek dari perjanjian tersebut haruslah jelas dan tidak bertentangan dengan hukum. Meskipun perjanjian jual beli BPKB tanpa kendaraan merupakan hal yang tabu, namun untuk berbagai kalangan hal ini merupakan hal yang sudah biasa dilakukan. Biasanya orang yang menjualkan BPKB tanpa kendaraan adalah orang-orang yang motornya dicuri hingga hanya tersisa surat saja, atau orang yang menjual motornya dengan tidak utuh, yang dijual adalah mesinnya, rangka, cover dan yang lainnya, dalam pelaksanaannya menjual motor perbagian akan memberikan keuntungan yang berlipat ganda dibandingkan dengan menjual motor utuh, sehingga hal inilah yang menarik minat dari penjual untuk memasarkan bagian-bagian motornya secara terpisah. Maka keempat syarat perjanjian tersebut dikelompokkan dalam dua bentuk unsur yaitu syarat subyektif dan syarat obyektif. Dalam syarat subyektif terdiri dari

14 Lisnawati, L. (2017). "Motor Kawin": Suatu Bentuk Pemanfaatan Secara Tidak Sah Surat Tanda Nomor Kendaraan Bermotor (STNKB) (Studi Kasus Terhadap Q Dan P). Jurnal Kriminologi Indonesia, 8(2).

${ }^{15}$ Moonti, R. M. (2012). Pengaruh Internet dan Implikasinya terhadap perjanjian jual beli. Jurnal Legalitas, 5(01). 
kesepakatan antara kedua belah pihak yang melakukan perjanjian dan kecakapan hukum, apabila syarat subyektif ini tidak terpenuhi maka perjanjian dapat dibatalkan artinya selama para pihak tidak membatalkan perjanjian, maka perjanjian masih tetap berlaku. Sedangkan yang dimaksud syarat obyektif adalah suatu hal tertentu atau suatu sebab yang halal, dalam hal ini berhubungan dengan obyek yang diperjanjikan dan yang akan dilaksanakan oleh para pihak sebagai prestasi atau utang dari para pihak, apabila syarat obyektif ini tidak terpenuhi, maka perjanjian batal demi hukum yang artinya sejak semula dianggap tidak pernah ada perjanjian. Dalam perjanjian jual beli BPKB tanpa kendaraan sudah jelas apabila syarat obyektifnya tidak terpenuhi maka perjanjian tersebut batal demi hukum atau keberadaan perjanjian tersebut sejak awal dianggap tidak ada. Sudah seharusnya dibuat suatu peraturan yang jelas mengenai apakah boleh jual beli BPKB itu dilakukan, mengingat hanya pihak kepolisian yang dibolehkan untuk menerbitkan BPKB itu sendiri. Agar ke depannya masyarakat tidak bingung lagi atau menderita kerugian dikarenakan minimnya informasi mengenai jual beli BPKB tanpa kendaraan.

\section{Daftar Pustaka}

Buku

Ibrahim, Johnny, 2013, Teori dan Metodologi Penelitian Hukum Normatif, Malang: Bayu Media Publishing

Muhammad, Abdul Kadir, 2004, Hukum Perjanjian, Bandung: Pustaka Yustitia

\section{Jurnal}

Akhmaddhian, S., \& Agustiwi, A. (2018). Perlindungan Hukum Terhadap Konsumen Dalam Transaksi Jual Beli Secara Elektronik Di Indonesia. UNIFIKASI: Jurnal Ilmu Hukum, 3(2), 40-60. https:// doi.org/10.25134/unifikasi.v3i2.409

Anggraeni, R. D., \& Rizal, A. H. (2019). Pelaksanaan Perjanjian Jual Beli Melalui Internet (E-Commerce) Ditinjau Dari Aspek Hukum Perdataan. SALAM: Jurnal $\begin{array}{llll}\text { Sosial dan } & \text { Budaya } & \text { 223-238 }\end{array}$ http://dx.doi.org/10.15408/sjsbs.v6i3.11531

Bintoro, R. W. (2011). Penerapan Hukum dalam Penyelesaian Sengketa Transaksi Elektronik di Peradilan Umum. Jurnal Dinamika Hukum, 11(2), 258-272. http://dx.doi.org/10.20884/1.jdh.2011.11.2.185

Dewi, M. N. K. (2017). Penyelesaian Sengketa Dalam Perjanjian Jual Beli Secara Online. Jurnal Cahaya Keadilan, 5(2), 72-90. https://doi.org/10.33884/jck.v5i2.799

Dewi, S. A. K. (2015). Perjanjian Jual Beli Barang Melalui Elektronik Commerce (ECom). Jurnal Ilmiah Teknologi Informasi Asia, 9(2), 1-5.

Langi, M. (2016). Akibat Hukum Terjadinya Wanprestasi dalam Perjanjian Jual Beli. Lex Privatum, 4(3).

Lisnawati, L. (2017). "Motor Kawin": Suatu Bentuk Pemanfaatan Secara Tidak Sah Surat Tanda Nomor Kendaraan Bermotor (STNKB)(Studi Kasus Terhadap Q Dan P). Jurnal Kriminologi Indonesia, 8(2).

Moonti, R. M. (2012). Pengaruh Internet dan Implikasinya terhadap perjanjian jual beli. Jurnal Legalitas, 5(01).

Perdana, A., \& Dahlan, M. (2014). Penyelesaian wanprestasi dalam perjanjian jual beli melalui media elektronik. Jurnal Ilmu Hukum,2(1). Prasnowo, A. D., \& Badriyah, S. M. (2019). Implementasi Asas Keseimbangan Bagi Para Pihak 
Dalam Perjanjian Baku. Jurnal Magister Hukum Udayana, 8(1). https://doi.org/10.24843/JMHU.2019.v08.i01.p05

Salami, R. U., \& Bintoro, R. W. (2013). Aletrnatif Penyelesaian Sengketa Dalam Sengketa Transaksi Elektronik (E-Commerce). Jurnal Dinamika Hukum, 13(1), 124-135. http://dx.doi.org/10.20884/1.jdh.2013.13.1.161

Sidik, S. (2013). Dampak Undang-Undang Informasi dan Transaksi Elektronik (UU ITE) terhadap Perubahan Hukum dan Sosial dalam Masyarakat. Jurnal Ilmiah Widya, 4(2).

Zainati, A. (2018). Perjanjian Jual Beli Online dalam Kitab Undang-Undang Hukum Perdata dan Kompilasi Hukum Ekonomi Syariah (Doctoral dissertation, IAIN Purwokerto). http://dx.doi.org/10.20884/1.jdh.2011.11.2.185

\section{Website}

Polisi Republik Indonesia, Url: https://www.polri.go.id/layanan-bpkb"

\section{Peraturan Perundang-Undangan}

Kitab Undang-Undang Hukum Perdata, Burgelijk Wetboek voor Indonesie, Staatsblad Tahun 1847 Nomor 23.

Undang-Undang Nomor 19 Tahun 2016 Tentang Perubahan Atas Undang-Undang Nomor 11 Tahun 2008 Tentang Informasi dan Transaksi Elektronik, Lembaran Negara Republik Indonesia Tahun 2016 Nomor 251, Tambahan Lembaran Negara Republik Indonesia Nomor 5952.

Peraturan Kepolisian Republik Indonesia Nomor 5 Tahun 2012 Tentang Registrasi dan Identifikasi Kendaraan Bermotor, Lembaran Negara Republik Indonesia. 